\title{
Nitrogen budget of Apalachicola Bay, a bar-built estuary in the northeastern Gulf of Mexico
}

\author{
Behzad Mortazavi ${ }^{1, *}$, Richard L. Iverson ${ }^{1}$, Wenrui Huang ${ }^{2}$, F. Graham Lewis ${ }^{3}$, \\ Jane M. Caffrey ${ }^{4}$ \\ 'Department of Oceanography, Florida State University, Tallahassee, Florida 32306-4320, USA \\ ${ }^{2}$ FAMU-FSU College of Engineering, 2525 Pottsdamer St., Tallahassee, Florida 32310-6046, USA \\ ${ }^{3}$ Northwest Florida Water Management District, Route 1, Box 3100, Havana, Florida 32333 9700, USA \\ ${ }^{4}$ Institute of Marine Science, University of California Santa Cruz, Earth \& Marine Science Building, Santa Cruz, \\ California 95604, USA
}

\begin{abstract}
Apalachicola Bay, a bar-built, sub-tropical estuary in the northeastern Gulf of Mexico (GOM), USA, receives freshwater from the Apalachicola River and exchanges water with the GOM at 4 sites. The output from a 3-dimensional circulation model and nitrogen measurements in the river and the estuary over a 2 yr period were used to determine nitrogen input to the estuary and exchange with the GOM. The Apalachicola River was the major nitrogen source to the estuary and accounted for 92 and $73 \%$ of the total dissolved inorganic and organic nitrogen (DIN and DON) input, respectively. Nitrogen input from the GOM provided the remainder. DIN comprised $61 \%$ of total dissolved nitrogen (TDN) input to the estuary from the river and $26 \%$ of TDN input from the GOM. Maxima in TDN input to the estuary occurred during the high river-flow period (October to February). In contrast, TDN input minima occurred during the summer (May to September), when river flow was low. Benthic ammonium flux to the water column was maximum during the summer. However, it was not large enough to satisfy phytoplankton nitrogen demand during that period. The fraction of DIN input that was exported to the GOM increased linearly as estuarine water residence time decreased from 2 wk during summer to less than $3 \mathrm{~d}$ during winter. Seasonal nitrogen budgets indicated that DIN export to the GOM was maximum during winter $\left(87 \pm 5.4 \mathrm{mg} \mathrm{N} \mathrm{m}^{-2} \mathrm{~d}^{-1}\right)$ and minimum during summer $\left(9 \pm 1.4 \mathrm{mg} \mathrm{N} \mathrm{m}^{-2} \mathrm{~d}^{-1}\right)$. In contrast to the large decrease in DIN export to the GOM between these 2 periods, DON export to the GOM decreased from $81 \pm 5.8 \mathrm{mg} \mathrm{N} \mathrm{m}^{-2} \mathrm{~d}^{-1}$ during winter to only $45 \pm 3.2 \mathrm{mg} \mathrm{N} \mathrm{m} \mathrm{m} \mathrm{d}^{-1}$ during summer. Estimated denitrification rates indicated that $9 \%$ of the annual total nitrogen input to the estuary was removed by that mechanism. The $f$ ratio in Apalachicola Bay varied from 0.11 during the summer to 0.74 during the winter and averaged 0.19 for a 2 yr period. On an annual basis, DON input to the estuary and export to the GOM were in balance, while $66 \%$ of DIN input to the estuary was exported to the GOM. The nitrogen budget for Apalachicola Bay was balanced to within $6 \%$ of total nitrogen input.
\end{abstract}

KEY WORDS: Estuary - Nitrogen budget $\cdot$ DIN $\cdot$ DON $\cdot$ New production $\cdot f$ ratio

\section{INTRODUCTION}

Estuaries, located at the freshwater and saltwater interface, are more productive than either the river flood plains or the seas bordering them (Odum 1971) Rivers supply dissolved and particulate nutrients to estuaries. The particle-bound nutrients are thought to be less reactive (Benner et al. 1992) and readily

•E-mail: mortazavi@ocean.fsu.edu sequestered within the estuary following sedimentation (Pennock et al, 1999). However, dissolved nutrients retained in the estuary become available for incorporation by higher trophic levels after uptake and processing by the phytoplankton and the microbial community (Seitzinger \& Sanders 1997).

Human activities impact estuaries by altering freshwater inflow (Humborg et al. 1997) and/or by modifying river nutrient input to estuaries (Tumer \& Rabalais 1994). A reduction in freshwater inflow to estuaries 


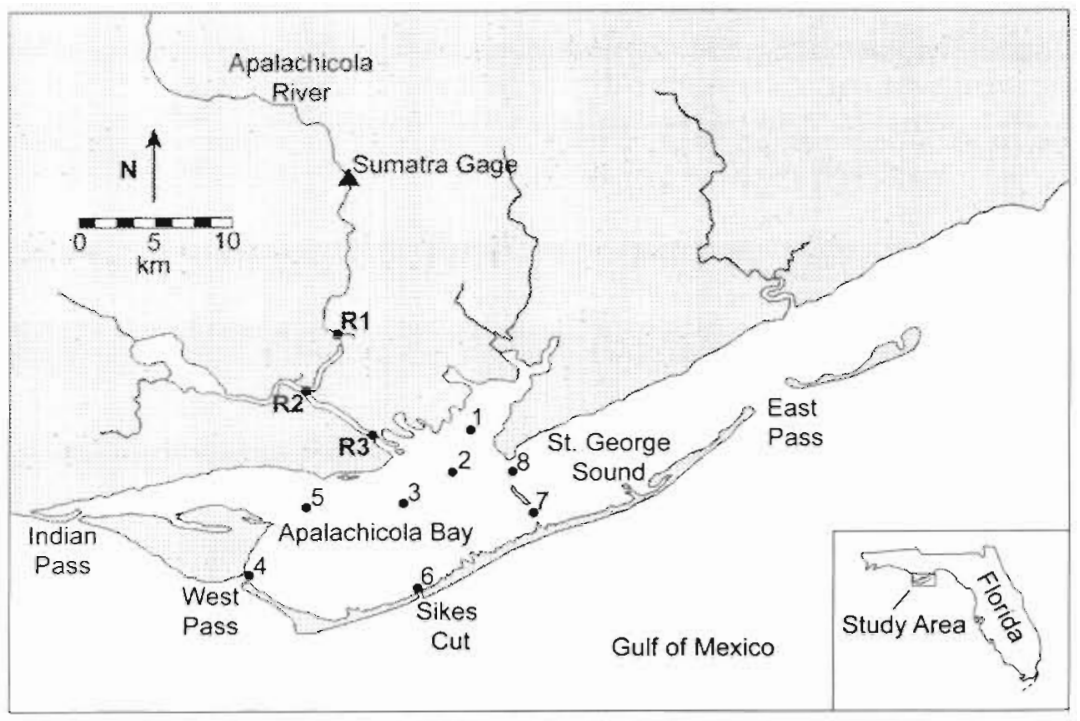

Fig. 1. Apalachicola River and estuary were sampled at Stns R1 through R3, and 1 through 8, respectively, from June 1994 through April 1995. Benthic flux measurements were performed at $\operatorname{Stn} 3$ estuaries were not available for inclusion in the Nixon et al. (1996) analysis. In nitrogen budget calculations for coastal plain estuaries, net nutrient export at the seaward boundary has been determined by the difference between nitrogen input and nitrogen sediment accumulation plus denitrification rates (Boynton et al. 1995, Nixon 1995, Nixon et al. 1996). However, nutrients are exchanged at the seaward boundary at more than 1 point in bar-built estuaries. Since each seaward exchange site may be a nutrient source or sink, net nutrient export at the seaward boundary of bar-built estuaries cannot be calculated from the difference between element river input and sediment accumulation rates and other internal losses. In this paper we report a determination and analysis of the nitrogen budget of Apalachicola Bay, a bar-built estuary after river impoundments or droughts can impact the estuarine food web by modifying the phytoplanktonbenthic macrophyte ratio (Baird \& Heymans 1996) or the relative abundance of the herbivores and carnivores (Livingston et al. 1997). Alternatively, excess nutrient input to estuaries can cause hypoxic or anoxic events (Rabalais et al. 1996), an increase in noxious algal bloom frequencies (Hallegraeff 1993), and a reduction in seagrass communities (Orth \& Moore 1983)

In response to concerns about eutrophication of coastal and estuarine environments (Nixon 1995), nutrient budgets have been constructed to examine the magnitude and temporal variability in nutrient input to estuaries. Boynton et al. (1995) suggested that nutrient budgets should be developed for estuaries of different morphology and hydrology to increase our understanding of ecosystem-scale nutrient dynamics.

Nixon et al. (1996) compiled annual nitrogen (N) and phosphorus (P) budgets for water body classes such as lakes, estuaries, fjords, coastal embayments and northern hemisphere inland seas to determine the fate of $\mathrm{N}$ and $P$ at the land-sea interface. The results of that analysis highlighted the importance of hydrology in retaining these elements within the various ecosystems. An increasing fraction of nutrient input to estuaries is retained with increasing water residence time (Nixon et al. 1996).

Knowledge of estuarine nutrient biogeochemistry is based mainly on results of investigations of coastal plain, drowned river estuaries, such as those classified by Cameron \& Pritchard (1963). Data from bar-built located in the northeastern Gulf of Mexico (GOM). The estuary receives freshwater from the Apalachicola River, the third largest river in the northern GOM (Bianchi et al. 1999), and exchanges water with the GOM at 4 sites (Fig. 1). In response to concerns over possible water reallocation within the upper portions of the river watershed and its impact on the estuarine productivity, a multi-disciplinary study of the river basin and estuary was initiated in 1993 (Lewis 1997). Nitrogen is the nutrient that most frequently limits phytoplankton productivity and biomass in Apalachicola Bay (Myers \& Iverson 1981, Fulmer 1997). We combined the output from a 3-dimensional hydrodynamic circulation model of the estuary with monthly measurements of nitrogen concentration in the river and estuary. Phytoplankton nitrogen demand (PND) and benthic nitrogen processes were included in calculations aimed at determining the magnitude and variability in nitrogen input to the estuary and export to the GOM on seasonal and annual time scales. We were specifically interested in determining the relative contribution of Apalachicola River and the GOM to the nitrogen budget of the estuary.

\section{METHODS}

Study site and sample collection. Apalachicola Bay has an area of $260 \mathrm{~km}^{2}$ and a mean depth of $2.2 \mathrm{~m}$. It is situated in the northeastern GOM (Fig. 1) and is an important nursery ground for many commercially important fish and invertebrates (Livingston 1984). 
The estuary provides $90 \%$ of Florida's oyster landing (Wilber 1992). The drainage basin (area $=45000 \mathrm{~km}^{2}$ ) which feeds the Apalachicola River is considered as one of the least polluted in the US (Livingston 1984).

The Apalachicola River daily discharge, measured at Sumatra (Fig. 1), was obtained from the US Geological Survey (USGS). Monthly measurements of hydrographic, chemical and biological variables were made from June 1994 through May 1996 at 3 Apalachicola River locations and 8 stations in the estuary (Fig. 1). Temperature and salinity were measured in situ with a factory calibrated YSI ${ }^{\otimes}$ salinometer. Surface river water and surface and bottom estuarine water samples were collected for nutrient analysis. Samples were placed in clean polyethylene bottles and kept on ice in the dark for transport to the laboratory, where they were filtered through GF/F filters and analyzed within $24 \mathrm{~h}$.

Analytical methods. Nitrate concentrations were determined with the chemiluminescence detectorbased method for trace nitrite $\left(\mathrm{NO}_{2}^{-}\right)$and nitrate $\left(\mathrm{NO}_{3}{ }^{-}\right)$in aqueous samples. The method was developed by Cox (1980) and applied to seawater analyses by Garside (1982). We used the modified version of Garside's method (Braman \& Hendrix 1989) with a Thermo Environmental ${ }^{\circledR}$ Model 42 chemiluminescence $\mathrm{NOx}$ analyzer. Because $\mathrm{NO}_{2}^{-}$is also reduced by this method, the procedure gives $\mathrm{NO}_{3}{ }^{-}$plus $\mathrm{NO}_{2}{ }^{-}$. Nitrite concentration measured colorimetrically (Strickland \& Parsons 1972) was subtracted from the total value to yield $\mathrm{NO}_{3}{ }^{-}$concentration. Ammonium $\left(\mathrm{NH}_{4}{ }^{+}\right)$ was determined with the phenol-hypochlorite method as outlined in Strickland \& Parsons (1972). Dissolved organic nitrogen (DON) was determined by the persulfate oxidation technique according to Pujo-Pay \& Raimbault (1994).

Sediment nitrogen experimental methods. During the study period, benthic dissolved inorganic nitrogen (DIN) flux measurements were made on 9 occasions. Between 8 and 10 undisturbed sediment cores $(8.7 \mathrm{~cm}$ diameter) were collected by divers at Stn 3 (Fig. 1). The cores were brought to the laboratory and allowed to equilibrate with circulating water overnight in the dark at the ambient estuarine water temperature, as recommended by Sloth et al. (1992). The following day, before being sealed, water height in each core was adjusted to $10 \mathrm{~cm}$ and a $2 \mathrm{~cm}, 25 \% \mathrm{O}_{2}$ in air headspace was established. Slow water stirring was established with a rotating magnet activated by a motor attached to each core tube. Samples for $\mathrm{NO}_{3}{ }^{-}, \mathrm{NO}_{2}{ }^{-}$, and $\mathrm{NH}_{4}{ }^{+}$ were collected at $1.5 \mathrm{~h}$ intervals for $6 \mathrm{~h}$, immediately filtered through GF/F filters and frozen for later analysis. A mixture of $25 \% \mathrm{O}_{2}$ in air was injected into the headspace when water samples were removed (Sloth et al. 1992). Linear regression analysis of concentration versus time on individual cores was used to determine DIN flux.

The same cores were used for nitrification rate determination with the acetylene inhibition technique (Sloth et al. 1992). Briefly, after the $6 \mathrm{~h}$ incubation, $60 \mathrm{ml}$ of saturated acetylene water was injected into 6 to 8 of the cores, while 2 were kept as controls. Samples were collected every $1.5 \mathrm{~h}$ for $6 \mathrm{~h}$, filtered through $\mathrm{GF} / \mathrm{F}$ filters and immediately frozen for $\mathrm{NH}_{4}{ }^{+}$analysis at a later time. $\mathrm{NO}_{3}{ }^{-}$fluxes were not measured in September and November 1994. Nitrification rates were determined by subtracting the $\mathrm{NH}_{4}{ }^{+}$flux before inhibition from rates after inhibition (Sloth et al. 1992, Caffrey \& Miller 1995) for each core when slopes of the regression lines before and after treatment were found to be significantly different (Sokal \& Rohlf 1981).

Denitrification rates were estimated by subtracting $\mathrm{NO}_{3}{ }^{-}$fluxes from nitrification rates under the assumptions (1) that nitrate ammonification was insignificant, (2) that the sediment $\mathrm{NO}_{3}{ }^{-}$pool was not changing during the incubation period (Caffrey et al. 1993), and (3) that benthic microalgae were not significantly affecting the nitrogen fluxes across the sedimentwater interface. For September and November 1994 we assumed that $\mathrm{NO}_{3}^{-}$flux was equal to the mean $\mathrm{NO}_{3}^{-}$flux for all the other months.

Water budget calculations. Water exchange with the GOM was determined for Apalachicola Bay with a 3 dimensional, time-dependent, numerical hydrodynamic model that allowed velocity, temperature and salinity field calculations. A Blumberg \& Mellor (1980, 1987) model application to Apalachicola Bay used an explicit-in-horizontal, implicit-in-vertical, finite-difference format with freshwater inflow, tide, and wind stress forcing. The set of governing equations is given by Blumberg \& Herring (1987). The model solved a coupled system of differential, prognostic equations describing conservation of mass, momentum, heat, and salinity at each of 930 horizontal grids and 5 vertical layers of the computational scheme. A horizontal, orthogonal, curvilinear coordinate system allowed representation of coastline irregularities. A sigma-coordinate system allowed vertical stretching to simulate water level changes in the estuary. A turbulence closure sub-model, which provides eddy viscosity and eddy diffusivity for vertical mixing, permitted variation in the forcing factors (Mellor \& Yamada 1982, Galperin et al. 1988). The model has been successfully applied to Chesapeake Bay (Blumberg \& Goodrich 1990) and Delaware Bay (Galperin \& Mellor 1990).

The model was calibrated and verified with hydrographic data recorded at $0.5 \mathrm{~h}$ intervals from in situ instruments located throughout the estuary during a 6 mo period (Huang \& Jones 1997). For simulations used in the present analysis, measured river discharge, 
winds, tides, temperature, and salinity were applied to the model as boundary conditions. The model was used to calculate water inflow and export at the passes. The estuarine water residence time was calculated by dividing the estuary's volume by the sum of the total water imported to the estuary.

Nitrogen input/export calculations. We used the results of the hydrodynamic circulation model combined with river flow and measurements of nitrogen species in the river and the estuary to estimate net DIN and DON input to the estuary. The daily river DIN and DON input to Apalachicola Bay and the estuary DIN and DON exchange with the GOM were calculated for each month. This involved multiplying the mean river discharge and mean seawater exchange at the passes, averaged over $4 \mathrm{~d}$ prior to each sampling, by the mean river and exchange site DIN and DON concentrations, respectively. Standard error values were estimated by
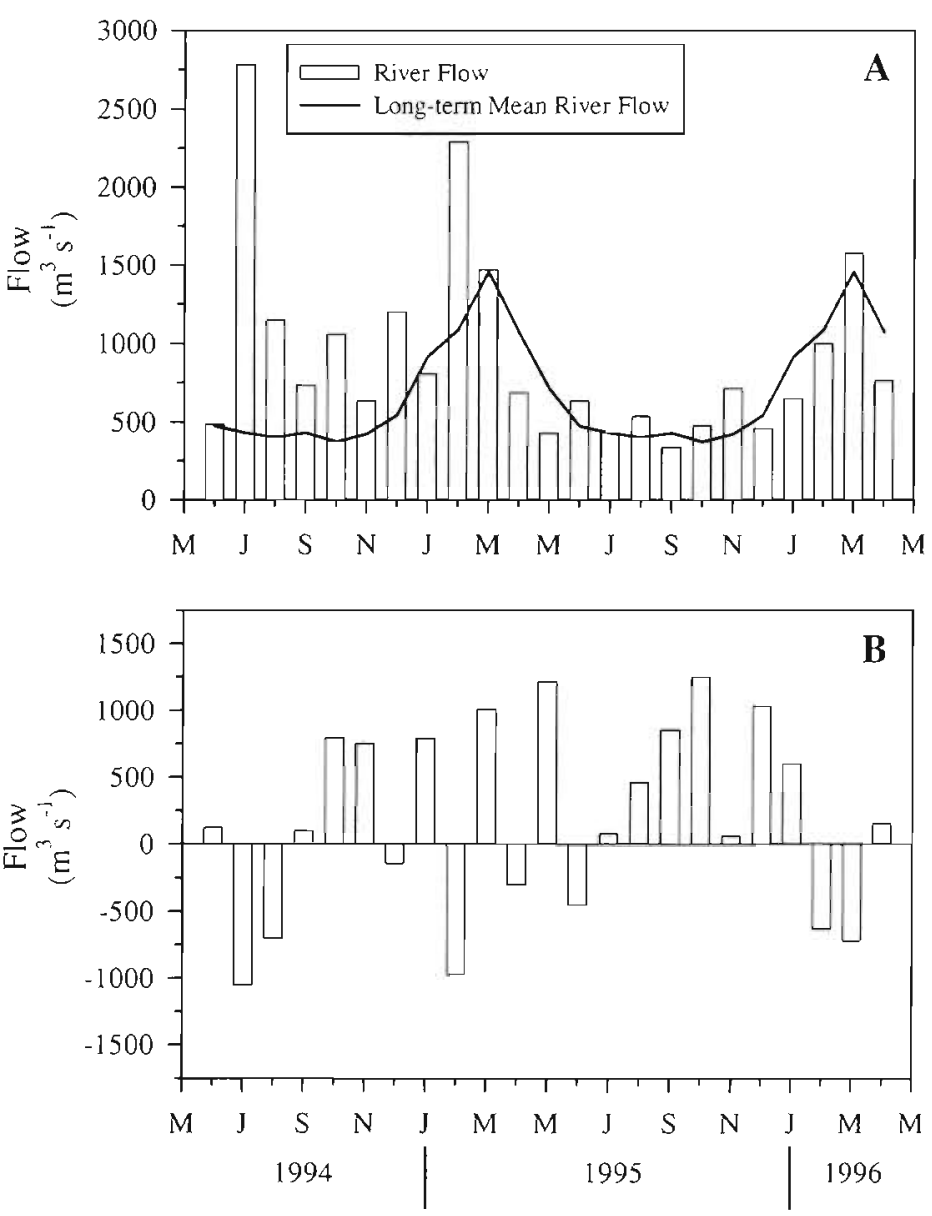

Fig. 2. (A) Long-term (1968 to 1989) mean Apalachicola River flow and mean river flow for $4 \mathrm{~d}$ prior to each sampling event. (B) Water exchange at the eastern boundary of the estuary determined from the hydrodynamic circulation model. Negative flow rates indicate estuarine water outflow to the GOM, and positive flow rates indicate GOM water inflow to the estuary error propagation throughout time, with the method of Morel \& Andre (1991).

$f$ ratio calculations. Dugdale \& Goering (1967) partitioned total phytoplankton nitrogen production into 'new' and 'regenerated' production. New production is supported by allochthonous nitrogen sources while regenerated production is supported by nitrogen recycled in situ through the food web of a system. Eppley \& Peterson (1979) later defined the ratio of new to total production as the $f$ ratio. Apalachicola Bay PND was calculated from daily primary productivity rates, which were measured monthly in Apalachicola Bay during the study period (Mortazavi et al. 2000). Carbon productivity rates were converted to nitrogen with the Redfield (1958) C:N ratio, which approximates the C:N ratio for Apalachicola Bay phytoplankton (Chanton 1997). Monthly $f$ ratios were calculated by dividing the fraction of net DIN input available to primary producers in the estuary by PND. The fraction of net DIN available to primary producers was determined by subtracting DIN input to the estuary from the sum of DIN exported from the estuary and taken up by the sediments.

\section{RESULTS}

\section{Hydrology}

The long-term (1965 to 1989) Apalachicola River monthly mean discharge is $710 \mathrm{~m}^{3} \mathrm{~s}^{-1}$ (Fu \& Winchester 1994). Discharge minima occur during the summer season, while the winter and early spring seasons are characterized by discharge maxima (Fig. 2A) in response to rainfall over the river drainage basin. Mean river discharge for the study period (June 1994 to May 1996) was $926 \pm$ $127 \mathrm{~m}^{3} \mathrm{~s}^{-1}( \pm 1 \mathrm{SE})$. The unusually high discharge in July 1994 was the result of several low-pressure atmospheric systems that delivered large amounts of rain throughout the watershed. After the flood, river flow remained high before resuming normal flows in winter 1995.

St. George Sound (Fig. 1) was the major source of GOM water to the estuary, and accounted for all the seawater input to the estuary, except in January 1996 , when $2 \%$ of GOM water entered the estuary through Bob Sikes Cut. Mean seawater input to the estuary for the 2 yr study period was $403 \pm 95 \mathrm{~m}^{3} \mathrm{~s}^{-1}$ (Fig. 2B). Lowest seawater flow into the estuary occurred during high river flow periods. Maximum GOM inflow $\left(1253 \mathrm{~m}^{3} \mathrm{~s}^{-1}\right)$ to the estuary occurred in October 1995 and exceeded the long-term mean river flow for that month by a factor of 3 (Fig. 2). Of the water out- 
flow from the estuary to the GOM, 67\% (range 11 to $87 \%$ ) occurred through West Pass (Fig. 1). However, in April 1995, St. George Sound was the major water outlet for the estuary and accounted for $67 \%$ of the total outflow.

\section{Dissolved nitrogen input and export}

No clear seasonality was observed in river DIN and DON concentrations (Fig. 3A). Mean river DIN concentration $\left(350 \pm 21 \mathrm{mg} \mathrm{N} \mathrm{m}^{-3}\right)$ was significantly higher than mean river DON concentration $(183 \pm 20 \mathrm{mg} \mathrm{N}$ $\mathrm{m}^{-3} \mathrm{j}$. DIN and DON concentrations at the estuary's eastern boundary were $115 \pm 20$ and $208 \pm 14 \mathrm{mg} \mathrm{N}$ $\mathrm{m}^{-3}$, respectively (Fig. $3 \mathrm{~B}$ ).

River nitrogen input to the estuary increased with increasing river flow (Fig. 4A). Maxima in river DIN and DON input (Fig. 4A) to the estuary occurred in July 1994 and February 1995, during times when river flows were maxima (Fig. 2A). Following the July 1994 flood, nitrogen input to the estuary remained relatively high compared to summer and fall 1995. DIN input to the estuary frequently exceeded DON input (Fig. 4A). On an annual basis DIN input represented $61 \%$ of the river total dissolved nitrogen (TDN) input (171 $\left.\pm 7.6 \mathrm{mg} \mathrm{N} \mathrm{m}^{-2} \mathrm{~d}^{-1}\right)$ to the estuary.

Nitrogen input through St. George Sound was, with the exception of January 1995. dominated by the organic form (Fig. 4B). This contrasts to the river TDN input, which was dominated by the inorganic form (Fig. 4A). Maximum DIN and DON inputs to the estuary from the GOM occurred in January and October 1995, respectively (Fig, 4B). Annually integrated DIN and DON inputs to the estuary from the GOM were $9 \pm 0.7$ and $25 \pm$ $2.1 \mathrm{mg} \mathrm{N} \mathrm{m}^{-2} \mathrm{~d}^{-1}$, respectively.

Minimum TDN export to the GOM occurred in summer 1995 (Fig. 4C), when river flow and river TDN input were low (Figs. 2A \& 4A) while maxima in export to the GOM occurred during July 1994 flood and the 1995 winter season (Fig. 4C). However, the seasonal pattern in DON export to the GOM was not as clear as the pattern in DIN export. The maxima in DON export occurred during the 1994 flood event (Fig 2A), while maxima in DIN export to the GOM occurred in March 1995 (Fig. 4C). Integrated DIN and DON export to the GOM for the duration of the study period were $75 \pm 4.7$ and $89 \pm 6.9 \mathrm{mg} \mathrm{N}$ $\mathrm{m}^{-2} \mathrm{~d}^{-1}$, respectively.

\section{Particulate phytoplankton nitrogen exchange}

Particulate phytoplankton nitrogen $\left(\mathrm{PN}_{\mathrm{chl}}\right)$ exchange with the GOM was determined from chlorophyll (chl) a concentration converted to nitrogen with a $1: 50 \mathrm{chl}: \mathrm{C}$ and the Redfield (1958) C:N ratios. Throughout the study $\mathrm{PN}_{\mathrm{chl}}$ export exceeded input (Fig. 5). Maxima in $\mathrm{PN}_{\mathrm{ch}}$ input to the estuary occurred in January 1995, while maximum export to the GOM occurred in March 1995 (Fig. 5). Annual $\mathrm{PN}_{\mathrm{chl}}$ input to the estuary and export to the GOM were equivalent to 2.5 and $9 \%$ of the combined river and GOM TDN input, respectively.

\section{Residence time and nitrogen retention}

Apalachicola Bay water residence time (mean $=6 \mathrm{~d}$ ) varied from $2.5 \mathrm{~d}$ during the high river flow periods to $12.5 \mathrm{~d}$, when river flow decreased to summer low values (Fig. 6A). The longest residence time periods in
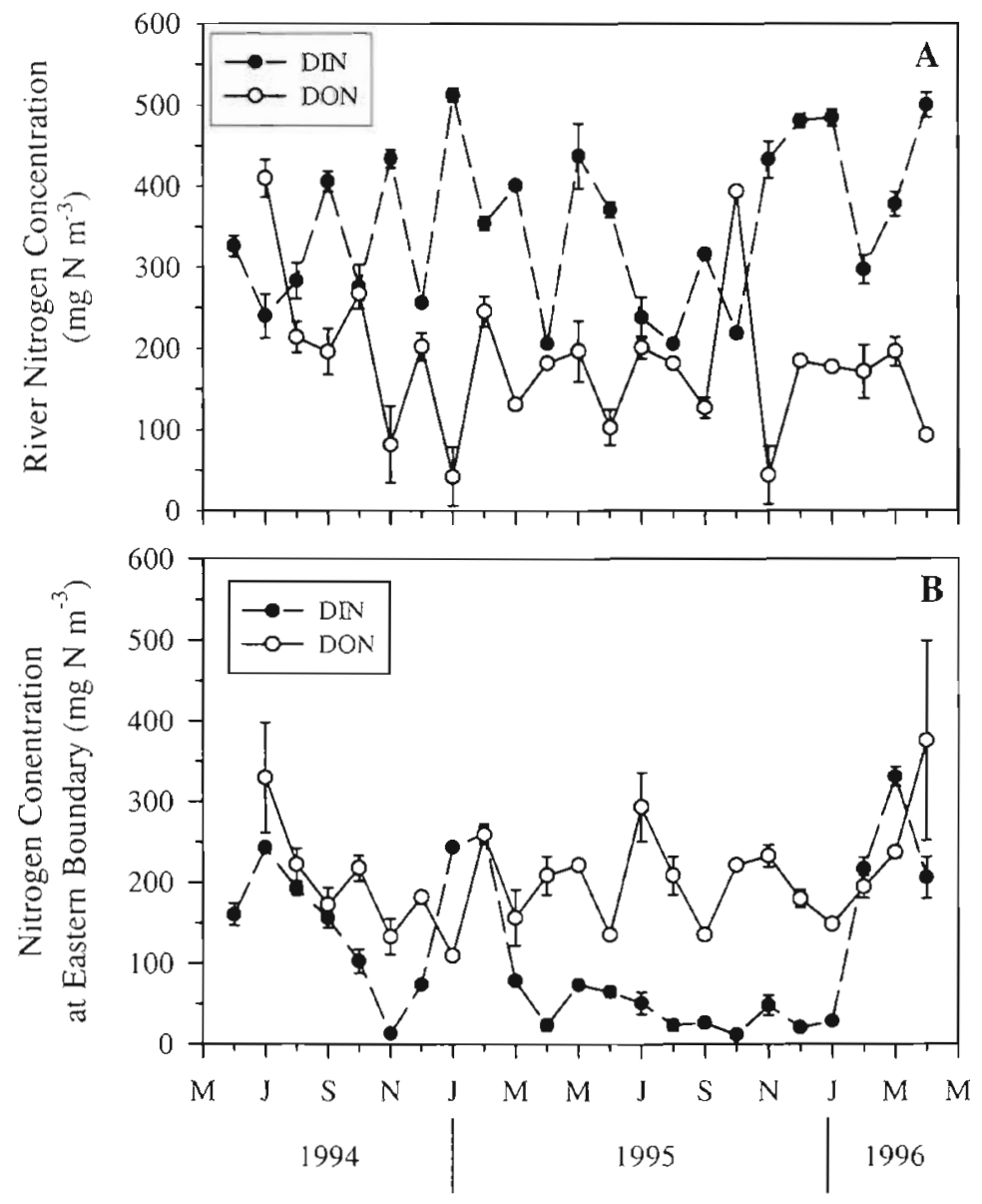

Fig. 3. Time series of mean ( $\pm 1 \mathrm{SE}$ ) DIN and DON concentrations $(A)$ in the river and $(B)$ at the eastern boundary of the estuary. DON samples were not collected in June 1994 

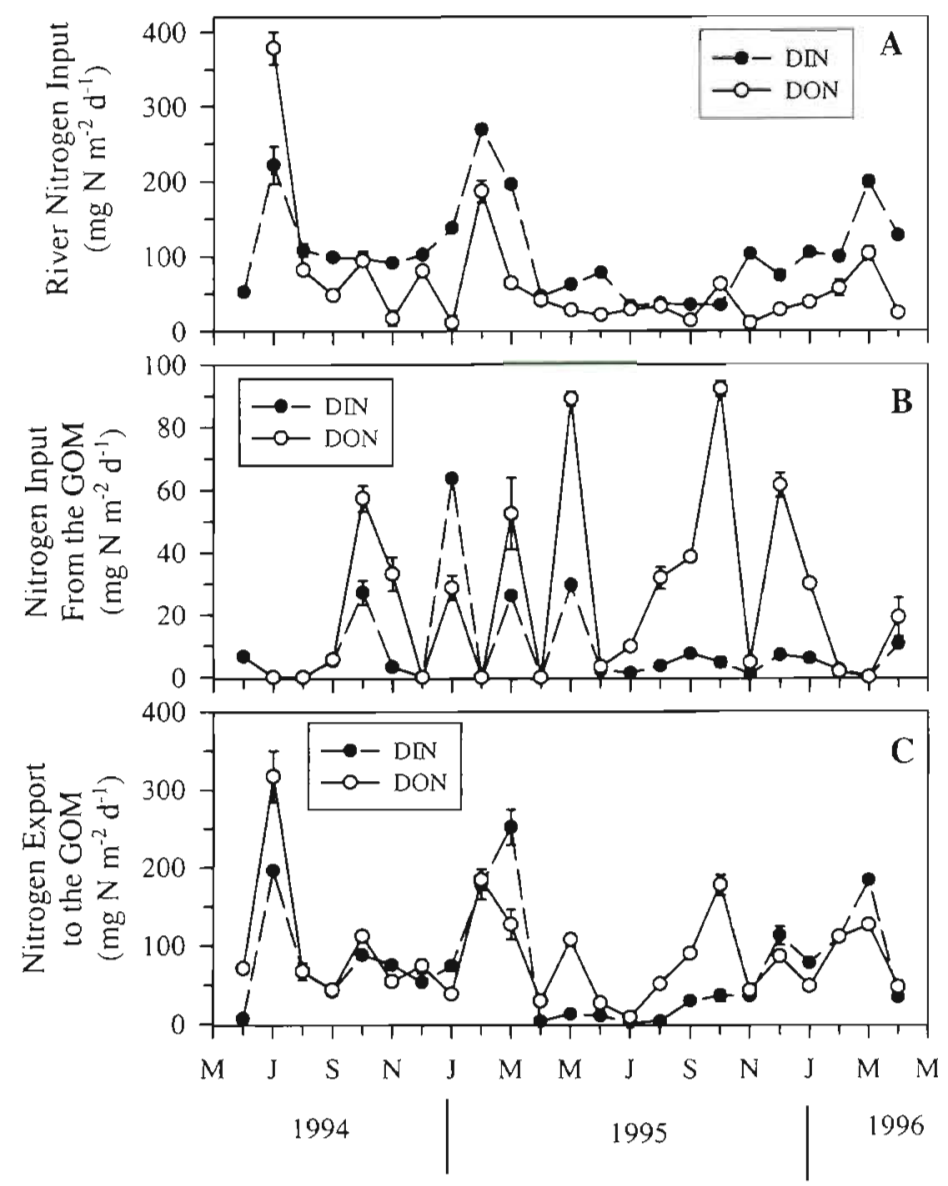

Fig. 4. Time series of mean ( $\pm 1 \mathrm{SE}$ ) (A) river and (B) marine DIN and DON input to the estuary and (C) marine DIN and DON export to the GOM. DON input to the estuary for June 1994 was not determined

\section{Benthic flux}

Benthic $\mathrm{NH}_{4}{ }^{+}$flux ranged from undetectable (November 1994) to a maximum of $42.0 \pm$ $1.2 \mathrm{mg} \mathrm{N} \mathrm{m}^{-2} \mathrm{~d}^{-1}$ during summer months, when estuarine water temperature was high (Fig. 8). Annually integrated $\mathrm{NH}_{4}{ }^{+}$flux to the overlying water was $16 \pm 1.1 \mathrm{mg} \mathrm{N} \mathrm{m} \mathrm{N}^{-2} \mathrm{~d}^{-1}$, providing recycled nitrogen to the water column at a rate equivalent to $14 \%$ of the total DIN input to the estuary.

In most instances, $\mathrm{NH}_{4}{ }^{+}$production rates increased after the addition of acetylene. However, for the periods when $\mathrm{NH}_{4}{ }^{+}$flux decreased following the acetylene addition (Table 1), we assumed that nitrification rates were below the detection limit. Significant nitrification rates were measured in summer and fall 1994, and winter 1996 (Table 1). Mean nitrification rate was $4 \pm 1.0 \mathrm{mg} \mathrm{N} \mathrm{m}^{-2}$ $\mathrm{d}^{-1}$ and varied from undetectable to a maximum of $19 \pm 1.3 \mathrm{mg} \mathrm{N} \mathrm{m} \mathrm{N}^{-2} \mathrm{~d}^{-1}$ in December 1994 (Table 1). Apalachicola Bay sediments were generally a sink for $\mathrm{NO}_{3}^{-}$(Fig. 8). Annually integrated benthic $\mathrm{NO}_{3}{ }^{-}$flux was $-17 \pm$ $3.6 \mathrm{mg} \mathrm{N} \mathrm{m} \mathrm{m}^{-2} \mathrm{~d}^{-1}$ and ranged from zero to a maximum of $-41 \pm 2.6 \mathrm{mg} \mathrm{N} \mathrm{m}^{-2} \mathrm{~d}^{-1}$ in February 1996 (Fig. 8). Estimated denitrification rates varied from undetectable to $48 \pm 4.4 \mathrm{mg}$ $\mathrm{N} \mathrm{m}{ }^{-2} \mathrm{~d}^{-1}$ in February 1996 (Table 1). On average, nitrification provided $10 \%$ of the $\mathrm{NO}_{3}{ }^{-}$annually used in denitrification, for a mean estimated denitrification rate of $21 \pm$ $3.5 \mathrm{mg} \mathrm{N} \mathrm{m}^{-2} \mathrm{~d}^{-1}$.
Apalachicola Bay (Fig. 6A) were concurrent with periods of low nitrogen input (Fig. 4) and high primary productivity (Mortazavi et al. 2000). As residence time decreased during high river flow periods (Fig. 2A), DIN export to the GOM increased (Fig. 4C). During periods when residence time exceeded $6 \mathrm{~d}, 27.8 \%$ $( \pm 11.0)$ of the DIN input to the estuary was exported. In contrast, $74.8 \%( \pm 8.3)$ of the DIN input was exported when residence time was less than $6 \mathrm{~d}$ (Fig. 6B). Nearly half of the variability in the fraction of DIN input to the estuary that is exported to the GOM is explained by residence time $\left(\mathrm{r}^{2}=0.48, F=17.94, \mathrm{p}<\right.$ 0.001 ). Annually, $34 \%$ of the DIN input to the estuary was exported to the GOM, with the fraction of DIN input exported increasing as estuarine water residence time decreased (Fig. 6B). This is in contrast to DON input and export which were balanced (Fig. 7).

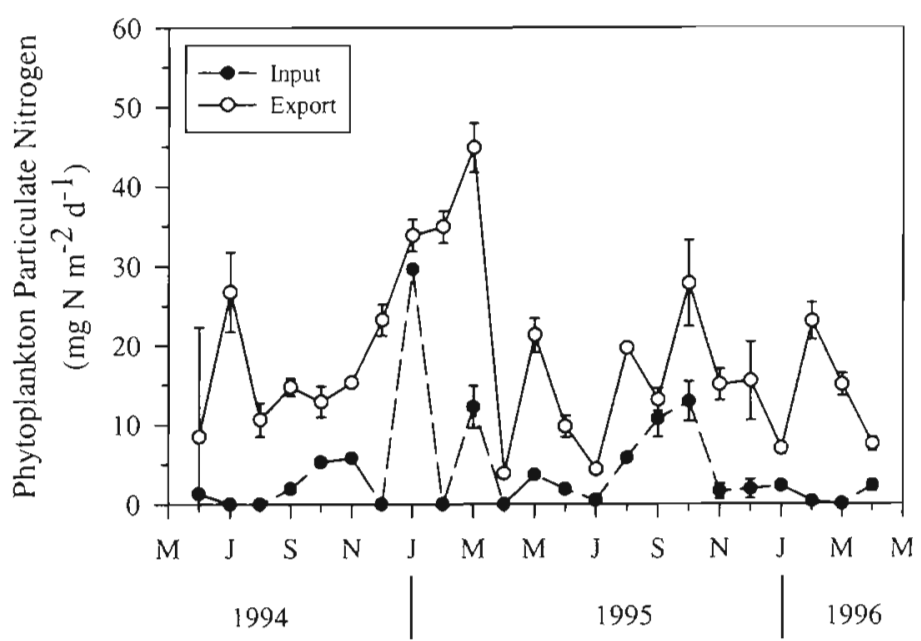

Fig. 5. Phytoplankton particulate nitrogen input to the estuary and export to the GOM determined from chlorophyll a concentrations converted to particulate nitrogen 


\section{Net nitrogen input and primary productivity}

Apalachicola phytoplankton productivity has a dis tinct seasonal pattern, with high rates measured during summer months, when photosynthetically active radiation and water temperature are high (Mortazavi et al. 2000). PND ranged from $17 \mathrm{mg} \mathrm{N} \mathrm{m}^{-2} \mathrm{~d}^{-1}$ in winter (February 1996) to a maximum of $300 \mathrm{mg} \mathrm{N} \mathrm{m}^{-2} \mathrm{~d}^{-1}$ in summer months (Fig. 9). Net DIN input to the estuary $\left(38 \pm 6.5 \mathrm{mg} \mathrm{N} \mathrm{m} \mathrm{N}^{-2} \mathrm{~d}^{-1}\right)$ was equivalent to $34 \%$ (range 0 to $100 \%$ ) of PND (Fig. 9).

\section{Apalachicola Bay nitrogen mass balance for high river flow periods}

The Apalachicola River had a mean discharge of $1198 \mathrm{~m}^{3} \mathrm{~s}^{-1}$ during the October 1994 to February 1995 period. The river supplied $134 \pm 3.5$ and $65 \pm 9.0 \mathrm{mg} \mathrm{N}$ $\mathrm{m}^{-2} \mathrm{~d}^{-1}$ of DIN and DON, respectively, to the estuary. GOM water entering the estuary through the passes transported DIN, DON, and $\mathrm{PN}_{\mathrm{chl}}$ at a rate of $22 \pm 1.0$, $22 \pm 2.8$, and $10 \pm 0.1 \mathrm{mg} \mathrm{N} \mathrm{m}^{-2} \mathrm{~d}^{-1}$, respectively (Fig. 10A). Significant amounts of DIN $\left(87 \pm 5.4 \mathrm{mg} \mathrm{N} \mathrm{m}^{-2} \mathrm{~d}^{-1}\right)$, DON $(81 \pm 5.8 \mathrm{mg} \mathrm{N}$ $\left.\mathrm{m}^{-2} \mathrm{~d}^{-1}\right)$, and $P N_{\text {chl }}\left(25 \pm 1.6 \mathrm{mg} \mathrm{N} \mathrm{m}^{-2} \mathrm{~d}^{-1}\right)$ were exported to the GOM. During this time, benthic $\mathrm{NH}_{4}^{+}$flux was insignificant. However, $\mathrm{NO}_{3}{ }^{-}$uptake by the sediments removed $5 \pm 2.4 \mathrm{mg} \mathrm{N} \mathrm{m}^{-2} \mathrm{~d}^{-1}$ from the water column. Denitrification accounted for a net loss of $15 \pm$ $2.1 \mathrm{mg} \mathrm{N} \mathrm{m}^{-2} \mathrm{~d}^{-1}$. PND for the October 1994 to February 1995 period was $88 \mathrm{mg} \mathrm{N} \mathrm{m}^{-2} \mathrm{~d}^{-1}$ (Fig. 7) and $65 \pm 7.0$ of the net $70 \pm 7.0 \mathrm{mg} \mathrm{N}$ $\mathrm{m}^{-2} \mathrm{~d}^{-1}$ DIN input to the estuary was used by phytoplankton as new production. The $f$ ratio for this period was 0.74 .

\section{Apalachicola Bay nitrogen mass balance for low river flow periods}

During May 1995 to September 1995 river flow averaged $474 \mathrm{~m}^{3} \mathrm{~s}^{-1}$. River DIN input to the estuary was $47 \pm 2.2 \mathrm{mg} \mathrm{N} \mathrm{m}^{-2} \mathrm{~d}^{-1}$, significantly higher than DIN input from the GOM $\left(6 \pm 0.6 \mathrm{mg} \mathrm{N} \mathrm{m}^{-2} \mathrm{~d}^{-1}\right)$ (Fig. 10B). However, river DON input $\left(26 \pm 2.5 \mathrm{mg} \mathrm{N} \mathrm{m}^{-2} \mathrm{~d}^{-1}\right)$ during this time was similar to GOM DON input $\left(26 \pm 1.7 \mathrm{mg} \mathrm{N} \mathrm{m}^{-2} \mathrm{~d}^{-1}\right)$ to the estuary. DIN and DON export to the GOM were $9 \pm 1.4$ and $45 \pm 3.2 \mathrm{mg} \mathrm{N} \mathrm{m} \mathrm{m}^{-2} \mathrm{~d}^{-1}$, respectively (Fig. 10B). Export of $\mathrm{PN}_{\text {chl }}\left(13 \pm 1.0 \mathrm{mg} \mathrm{N} \mathrm{m}^{-2}\right.$ $\mathrm{d}^{-1}$ ) was significantly greater than $P N_{c h l}$ import $\left(4 \pm 0.5 \mathrm{mg} \mathrm{N} \mathrm{m}^{-2} \mathrm{~d}^{-1}\right)$. Benthic $\mathrm{NH}_{4}{ }^{+}$flux was a significant nitrogen source and supplied the water column with $30 \pm 4.7 \mathrm{mg} \mathrm{N} \mathrm{m}^{-2} \mathrm{~d}^{-1}$. Nitrification rates were undetectable during this period. Nitrate influx into the sediment, where it was subsequently denitrified, occurred at a rate of $23 \pm 3.7 \mathrm{mg} \mathrm{N} \mathrm{m}^{-2} \mathrm{~d}^{-1}$. PND during this period was $186 \mathrm{mg} \mathrm{N} \mathrm{m}^{-2} \mathrm{~d}^{-1}$, of which $21 \mathrm{mg} \mathrm{N} \mathrm{m}^{-2} \mathrm{~d}^{-1}$ was supplied by net DIN input (44 \pm $2.7 \mathrm{mg} \mathrm{N} \mathrm{m}^{-2} \mathrm{~d}^{-1}$ ) to the estuary (Fig. 10B). The average $f$ ratio during this period was 0.11

\section{Annual nitrogen mass balance for Apalachicola Bay}

Mean river flow during the 2 yr study period was $926 \mathrm{~m}^{3} \mathrm{~s}^{-1}$, slightly higher than the long-term mean river discharge of $710 \mathrm{~m}^{3} \mathrm{~s}^{-1}$ (Fu \& Winchester 1994). The major nitrogen source to the estuary was the Apalachicola River, which accounted for $92 \%$ of total DIN input $(113 \pm$ $\left.4.6 \mathrm{mg} \mathrm{N} \mathrm{m}^{-2} \mathrm{~d}^{-1}\right)$ and $71 \%$ of total DON input $(92 \pm$ $6.5 \mathrm{mg} \mathrm{N} \mathrm{m}^{-2} \mathrm{~d}^{-1}$ ). Annually integrated DIN and DON export to the GOM were $75 \pm 4.7$ and $90 \pm 6.9 \mathrm{mg} \mathrm{N} \mathrm{m}^{-2}$ $\mathrm{d}^{-1}$, respectively (Fig. 10C). Benthic regeneration sup-
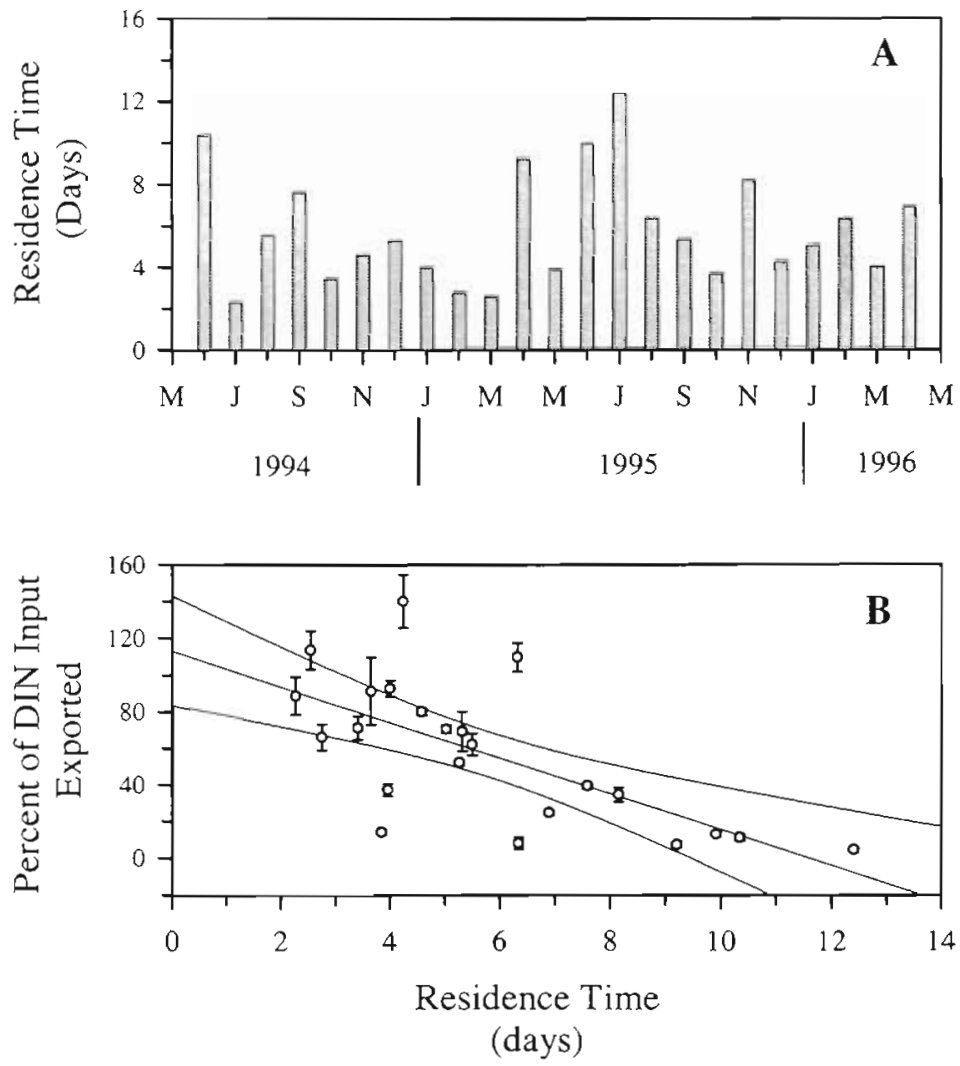

Fig. 6. (A) Estuarine water residence time determined from the hydrodynamic circulation model. (B) Percent of DIN input to the estuary exported to the GOM as a function of estuarine water residence time. The regression was significant at $p<0.005$ 


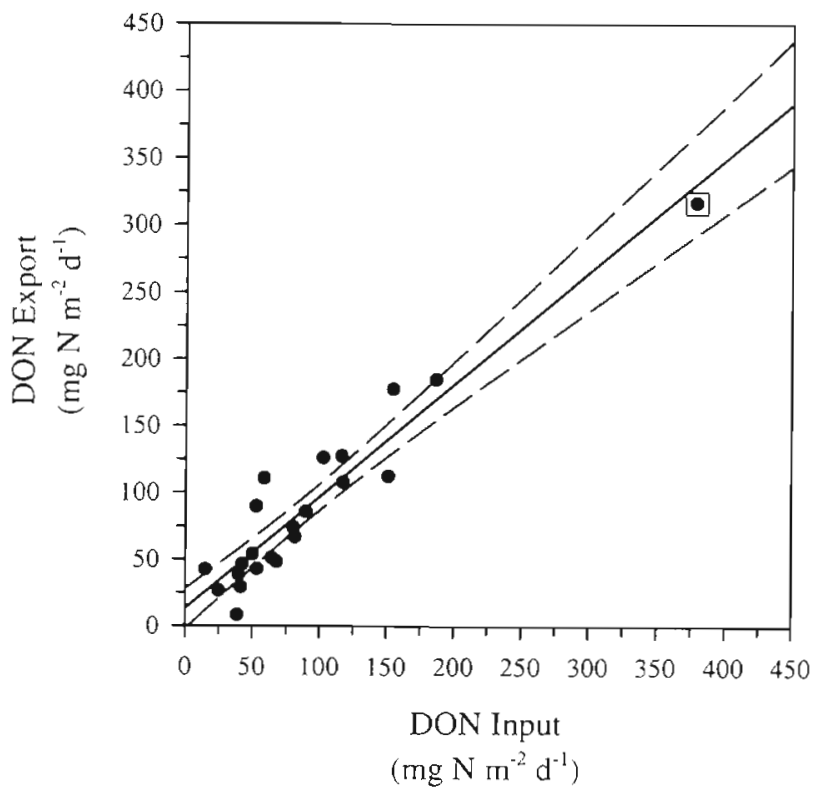

Fig. 7. DON export to the GOM as a function of DON input to the estuary. The slope was not significantly different from unity ( $t$-test, $p<0.05$ ). (•) July 1994 flood DON input the estuary and export to the GOM

plied an amount of nitrogen equivalent to $14 \%$ of total DIN input, while denitrification removed $19 \%$ of the DIN input to the estuary (Fig. $10 \mathrm{C}$ ). $\mathrm{PN}_{\mathrm{chl}}$ export from the estuary $\left(18 \pm 4.7 \mathrm{mg} \mathrm{N} \mathrm{m}^{-2} \mathrm{~d}^{-1}\right.$ ) exceeded input ( $5 \pm 0.5 \mathrm{mg}$ $\mathrm{N} \mathrm{m}^{-2} \mathrm{~d}^{-1}$ ). During the study period, $45 \%$ of the net DIN input to the estuary was denitrified, while the remainder was incorporated into phytoplankton new production (Fig. 10C). Annually integrated PND during the study period was $113 \mathrm{mg} \mathrm{N} \mathrm{m}^{-2} \mathrm{~d}^{-1}$, of which $22 \mathrm{mg} \mathrm{N} \mathrm{m}^{-2} \mathrm{~d}^{-1}$ was supplied with new nitrogen. Therefore, the longterm mean $f$ ratio for Apalachicola Bay is 0.19

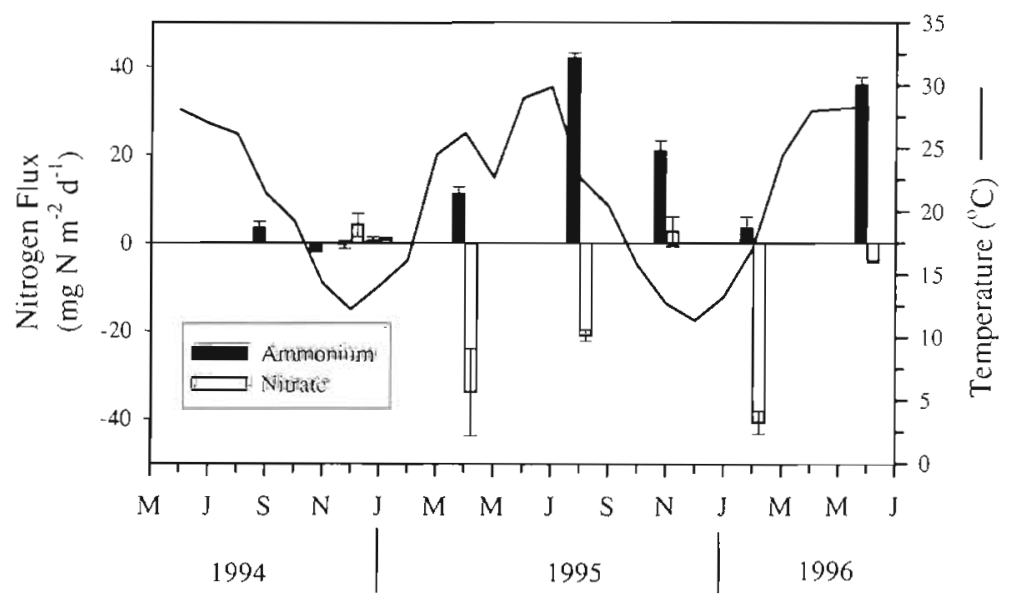

Fig. 8. Apalachicola Bay water temperature and mean ( $\pm 1 \mathrm{SE}$ ) benthic ammonium and nitrate flux rates. When error bars are not shown, errors are smaller than the symbol
Table 1. Apalachicola Bay nitrification and denitrification experimental results. Significant increase or decrease $(p<$ $0.05)$ in the slopes of $\mathrm{NH}_{4}{ }^{+}$fluxes after the acetylene addition was detected with an F-test (Sokal \& Rohlf 1981). Nitrification rates were determined by subtracting the $\mathrm{NH}_{4}{ }^{+}$flux before inhibition from rates after inhibition. BDL: instances when the 2 slopes were not significantly different. Denitrification rates were estimated by subtracting $\mathrm{NO}_{3}$ fluxes from nitrification rates. Values for nitrification and denitrification rates are means $\pm 1 \mathrm{SE}$

\begin{tabular}{|c|c|c|c|}
\hline Date & $\begin{array}{l}\text { No. of cores } \\
\text { receiving } \\
\text { acetylene }\end{array}$ & $\begin{array}{l}\text { Nitrification } \\
\text { rates } \\
\left.\text { (mg N m-2 } \mathrm{d}^{-1}\right)\end{array}$ & $\begin{array}{c}\text { Denitrification } \\
\text { rates } \\
\left(\mathrm{mg} \mathrm{N} \mathrm{m} \mathrm{N}^{-2} \mathrm{~d}^{-1}\right)\end{array}$ \\
\hline Sep 1994 & 8 & $9.7 \pm 1.8$ & $13.8 \pm 1.8$ \\
\hline Nov 1994 & 8 & $10.5 \pm 0.8$ & $14.6 \pm 0.9$ \\
\hline Dec 1994 & 6 & $18.6 \pm 1.3$ & $22.7 \pm 2.9$ \\
\hline Jan 1995 & 7 & $6.5 \pm 1.3$ & $7.5 \pm 1.4$ \\
\hline Арг 1995 & 6 & BDL & $33.9 \pm 9.9$ \\
\hline Aug 1995 & 6 & BDL & $21.0 \pm 1.3$ \\
\hline Nov 1995 & 6 & $\mathrm{BDL}$ & $2.7 \pm 3.3$ \\
\hline Feb 1996 & 8 & $7.5 \pm 3.6$ & $48.2 \pm 4.4$ \\
\hline Jun 1996 & 6 & BDL & $4.1 \pm 0.3$ \\
\hline
\end{tabular}

\section{DISCUSSION}

\section{Apalachicola Bay nitrogen mass balance}

Although there is a contribution from the GOM, the magnitude and seasonality of nitrogen input to Apalachicola Bay is mainly determined by the Apalachicola River flow pattern. River discharge increases during winter in response to high rainfall onto the upper watershed and to reduced terrestrial evapotranspiration. Despite the 1954 construction of Jim Woodruff dam at the confluence of the Chattahoochee and Flint Rivers, the Apalachicola River seasonal flow pattern has not significantly changed (Meeter et al. 1979).

The population density in the drainage basin that feeds the Apalachicola River is low (50 people $\mathrm{km}^{-2}$, Frick et al. 1996) and is, therefore, considered as one of the least polluted estuaries in the US (Livingston 1984). Based on measurements made by the USGS at a station $60 \mathrm{~km}$ upstream of the river mouth, the flow-adjusted $\mathrm{NO}_{3}{ }^{-}$concentration has not significantly changed between 1972 and 1990 (Frick et al. 1996). Mean DIN input to Apalachicola Bay, based on those measurements, was $34 \mathrm{~g} \mathrm{~N} \mathrm{~m}^{-2} \mathrm{yr}^{-1}$ and varied from 17 to $47 \mathrm{~g}$ $\mathrm{N} \mathrm{m} \mathrm{m}^{-2} \mathrm{yr}^{-1}$ (Frick et al. 1996). The mean annual river DIN input to the estuary of 38 $\pm 1.6 \mathrm{~g} \mathrm{~N} \mathrm{~m} \mathrm{~N}^{-1}$, estimated from our $2 \mathrm{yr}$ 


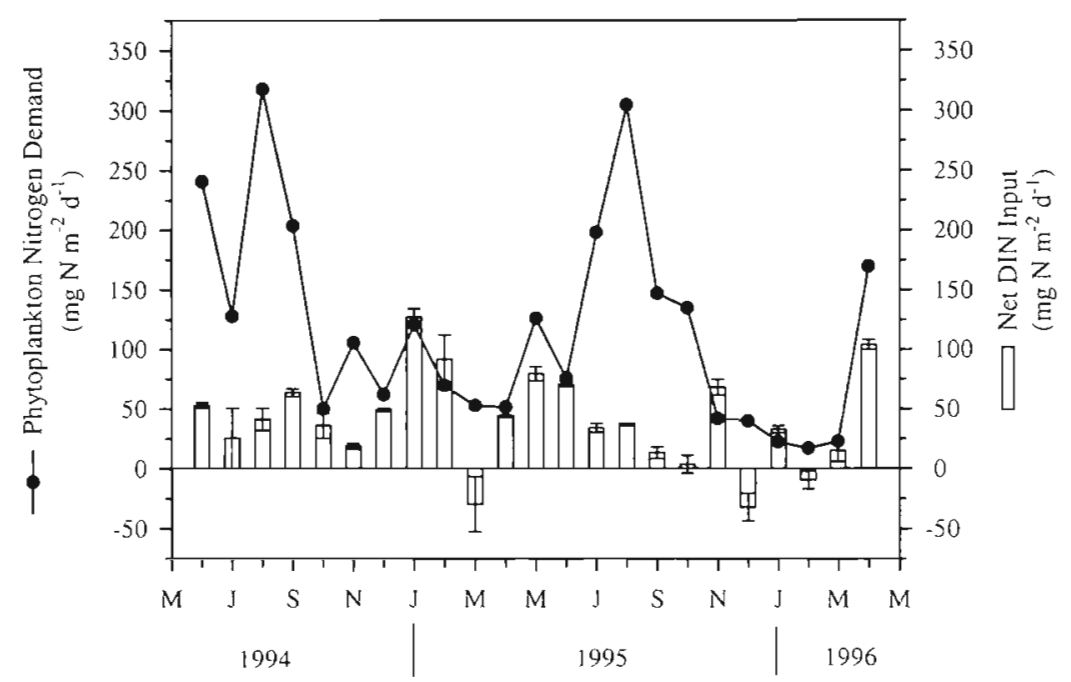

Fig. 9. Phytoplankton nitrogen demand (9) and net DIN input (open bars) to Apalachicola Bay from June 1994 to April 1996. Error bars are $\pm 1 \mathrm{SE}$

A greater fraction of sediment $\mathrm{NH}_{4}{ }^{+}$ efflux is expected at higher estuarine salinities (Gardner et al. 1991, Rysgaard et al. 1999). During the winter high river flow period, the average salinity in Apalachicola Bay was $<10$ PSU. With decreasing river flow, the salinity increased to $>25$ PSU during the summer months (Pennock et al. 1999). Increased ion exchange and ion pairing of $\mathrm{NH}_{4}{ }^{+}$, as a result of increased seawater cation concentration at higher salinities, cause increased sediment $\mathrm{NH}_{4}{ }^{+}$efflux (Gardner et al. 1991). The seasonal sediment ammonium flux differences in Apalachicola Bay (Fig. 10A,B) are consistent with that model and similar to rates measured in other GOM estuaries (Twilley et al. 1999).

The increased benthic $\mathrm{NH}_{4}{ }^{+}$flux during the summer season is impor-

study period, was similar to the long-term estimate made by the USGS.

We did not measure the contribution of nitrogen input by direct atmospheric deposition over the estuary's surface area. The long-term (1975 to 1984) mean monthly precipitation in Apalachicola is $15.7 \mathrm{~cm}$ (Livingston et al. 1997) and the volume associated with the rainfall over the estuary is equivalent to only $2 \%$ of the long-term mean monthly river discharge $\left(710 \mathrm{~m}^{3} \mathrm{~s}^{-1}\right)$. Based on measurements made from 1985 to 1991 , nitrogen input by atmospheric deposition to the Apalachicola River watershed ranged from 0.4 to $0.7 \mathrm{~g} \mathrm{~N} \mathrm{~m}^{-2} \mathrm{yr}^{-1}$ (Frick et al. 1996). By inference from these calculations, the nitrogen input by direct atmospheric deposition to the estuary was considered an insignificant term in the nitrogen budget of Apalachicola Bay compared to river nitrogen input.

Apalachicola Bay benthic nitrogen flux measurements made during the study period covered the annual ranges of nitrogen input to the estuary and water temperature. During the high river flow period, an amount of nitrogen equivalent to $6 \%$ of TDN input to the estuary was removed by denitrification. During the summer months, however, denitrification was a more significant loss term in the nitrogen budget of the estuary, with $22 \%$ of the summer TDN input to the estuary denitrified (Fig. 10B). During the summer lowriver-discharge period, water column $\mathrm{NO}_{3}{ }^{-}$was the main nitrogen source for denitrification and $\mathrm{NH}_{4}{ }^{+}$was released to the water column. In contrast, during the winter high flow period, nitrate produced by nitrification was the main nitrogen source for denitrification (Fig. 10A). tant in the estuary's nitrogen dynamics since it provides DIN to the water column at a rate similar to that of DIN input to the estuary. However, since only 11 and $16 \%$ of the summer PND were supplied through new nitrogen input and benthic regeneration, respectively, water column regeneration was the dominant nitrogen source, providing $73 \%$ of the PND (Fig. 10B). In contrast, during the winter season the main nitrogen source to the primary producers was new nitrogen supplied to the estuary by the river and the GOM. Water column regeneration supplied only $26 \%$ of PND (Fig. 10A) and benthic nitrogen flux was insignificant in the nitrogen budget during winter

The average PND during the study period was $113 \mathrm{mg} \mathrm{N} \mathrm{m} \mathrm{m}^{-2} \mathrm{~d}^{-1}$, of which 22 and $16 \mathrm{mg} \mathrm{N} \mathrm{m}^{-2} \mathrm{~d}^{-1}$ are supplied through new nitrogen availability and benthic regeneration, respectively (Fig 10C). Therefore, on an annual basis, water column regeneration annually supplied nitrogen to primary producers at a rate approximately 5 -fold greater than did benthic regeneration (Fig. 10C). The benthos represented a significant loss term in the nitrogen budget, since denitrification removed nitrogen that would otherwise be available to the primary producers at a rate equivalent to $19 \%$ of the annual DIN input to the estuary.

Annual river $\mathrm{PN}$ input to Apalachicola Bay is an estimated $33 \mathrm{mg} \mathrm{N} \mathrm{m}^{-2} \mathrm{~d}^{-1}$ based on a calculation which used river POC concentration (Mattraw \& Elder 1984) and a $\mathrm{C}: \mathrm{N}$ ratio (9.7 $\mathrm{g} \mathrm{g}^{-1}, \mathrm{n}=14$, Mortazavi unpubl. data) for river particulate matter. The annual nitrogen budget (Fig. 10C) indicated that all input terms combined, river TDN and PN plus TDN and $P N_{c h}$ from the GOM, to Apalachicola Bay were equivalent to $243 \pm 8.0 \mathrm{mg} \mathrm{N} \mathrm{m}^{-2}$ 
$\mathrm{d}^{-1}$. TDN and $P N_{c h l}$ export to the GOM plus denitrification and sedimentation were equivalent to $227 \pm 10.5 \mathrm{mg}$ $\mathrm{N} \mathrm{m}^{-2} \mathrm{~d}^{-1}$. The results of this budget, therefore, suggest that PN input and export, associated with detrital matter, to the estuary from the GOM are approximately in balance with a remainder of $16 \pm 13 \mathrm{mg} \mathrm{N} \mathrm{m}^{-2} \mathrm{~d}^{-1}$ net input, or $6 \%$ of total nitrogen input to the estuary.

\section{Estuarine nitrogen retention and loss}

Nixon et al. (1996) examined nitrogen retention and residence time, on an annual time scale, for a data set that included estuaries and enclosed seas. Nitrogen retention within these ecosystems decreased as water residence time decreased. In Apalachicola Bay, the fraction of monthly DIN input to the estuary that was retained increased as water residence time increased (Fig. $6 \mathrm{~B})$. On a seasonal time scale, the fraction of DIN input to the estuary that was retained decreased from $83 \%$ during the summer months, when the average residence time was $7.6 \pm 1.6 \mathrm{~d}$, to $45 \%$ during the winter months, when the average residence time was $4 \pm 0.4 \mathrm{~d}$.

Short-term experimental data suggested that DON is not retained long enough to be completely processed by the food web in short residence time estuaries (Seitzinger \& Sanders 1997). DON input to Apalachicola Bay and DON export to the GOM are balanced on monthly (Fig. 7), seasonal (Fig. 10A,B), and annual (Fig. 10C) time scales. Therefore, the DON budget for Apalachicola Bay corroborates the hypothesis proposed by Seitzinger \& Sanders (1997).

A greater fraction of total nitrogen input was denitrified as marine system

Fig. 10. Seasonal nitrogen box model for the periods (A) October 1994 to February 1995 and (B) May 1995 to September 1995 (C) Annual nitrogen box model. Nitrogen burial was estimated with a sedimentation rate of $4.2 \pm 0.4 \mathrm{~mm} \mathrm{yr}^{-1}$ (Hess 1995), a sediment dry gram density of $2.4 \mathrm{~g} \mathrm{~cm}^{-3}$ and a porosity of 0.7 (Mortazavi unpubl. data). River PN input to Apalachicola Bay is based on river POC concentration (Mattraw \& Elder 1984) and river particulate $\mathrm{C}: \mathrm{N}$ ratio $(9.7 \mathrm{~g}$ $\mathrm{g}^{-1}, \mathrm{n}=14$, Mortazavi unpubl. data). Values for nitrogen processes are means $( \pm 1 \mathrm{SE})$ in

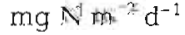


residence time increased, in the data set examined by Nixon et al. (1996). Nitrogen export at the seaward boundary, rather than denitrification, represents a significant loss term in estuaries with residence times of a few days to a few weeks, including Ochlockonee Bay (Nixon et al. 1996), Norsminde Fjord (Denmark; Nielsen et al. 1995), the Ems estuary (The Netherlands; van Beusekom \& de Jonge 1998), Boston Harbor (Nowicki et al. 1997), and Apalachicola Bay (this study). PN is considered non-reactive (Benner et al. 1992) and is either exported or buried in estuarine sediments (Pennock et al. 1999). If DON is not retained within short residence time estuaries, then denitrification becomes a more significant loss term in the nitrogen budget of short residence time estuaries when normalized to DIN input instead of to total nitrogen input. For example, denitrification removed nitrogen at a rate equivalent to $19 \%$ of the annual DIN input to Apalachicola Bay as opposed to $6 \%$ of the annual total nitrogen input.

\section{New production and the $f$ ratio in estuaries}

Only the fraction of primary production based on 'new' nutrients can be exported or removed by biological mechanisms without the pelagic system collapsing (Dugdale \& Goering 1967). Therefore, determination of new production is important in understanding the magnitude of biologically mediated carbon export from the pelagic system (Eppley \& Petersen 1979, Iverson et al. 2000) and control of higher trophic level production (Iverson 1990). New production rates in coastal and oceanic systems are determined from ${ }^{15} \mathrm{NO}_{3}{ }^{-}$uptake rates (Dugdale \& Goering 1967), changes in $\mathrm{NO}_{3}{ }^{-}$concentration (Boyd et al. 1995), or from export of organic matter from the euphotic zone (Wassmann 1990) coupled with knowledge of primary production rates. Nitrate is the 'new' nitrogen in these environments and is supplied to the euphotic zone by upwelling, diffusion, turbulent mixing, or after deep winter mixing. In estuaries, however, new nitrogen is supplied by rivers in various forms other than $\mathrm{NO}_{3}{ }^{-}$, including $\mathrm{NH}_{4}{ }^{+}$and urea. Therefore, new production rates cannot be determined from ${ }^{15} \mathrm{NO}_{3}{ }^{-}$uptake rates or changes in $\mathrm{NO}_{3}{ }^{-}$concentration, since $\mathrm{NO}_{3}^{-}$represents only a fraction of new nitrogen supplied to the system. Alternatively, determination of biogenic material exported from the euphotic zone in estuaries is complicated by input of terrestrial detrital matter, by storms and tides that resuspend the benthos, and by strong tidal exchange between the estuary and the bordering sea. These methodological difficulties have hampered new production rate measurements in estuaries.
Estuarine nutrient budgets coupled with primary productivity rate measurements provide an alternative tool for estimating new production. Nitrogen is the nutrient that most frequently limits phytoplankton production in estuaries (Howarth 1988). Measurement of nitrogen input and export rates and direct uptake by sediments can be used to determine the new nitrogen available to the primary producers.

Depending on location and season the $f$ ratio can vary between 0 and 1.0 in coastal waters (Eppley et al. 1979, Selmer et al. 1993, Bronk \& Ward 1999). During the summer season, when new nitrogen input to Apalachicola Bay was low and PND was high, the $f$ ratio was 0.11 (Fig. 10B). However, with increasing river flow during the October to February period, a greater fraction of the PND was supplied by river DIN input, and the $f$ ratio increased to 0.74 (Fig. 10A). Similarly, in a fjord in Norway, the $f$ ratio ranges from $<0.10$ during the summer to 0.76 following $\mathrm{NO}_{3}{ }^{-}$input to the water column in the spring (Paasche \& Kristiansen 1982).

In Apalachicola Bay, 66 and $15 \%$ of the 'new' DIN input to the estuary were exported to the GOM and taken up by the sediments, respectively (Fig. 10C). The available new DIN to the primary producers was $22 \mathrm{mg}$ $\mathrm{N} \mathrm{m}^{-2} \mathrm{~d}^{-1}$, which supplied $19 \%(f$ ratio $=0.19)$ of the annual PND (113 $\mathrm{mg} \mathrm{N} \mathrm{m} \mathrm{N}^{-2} \mathrm{~d}^{-1}$ ). The calculated $f$ ratio for Apalachicola Bay is at the lower limit of the theoretical annual curve (0.20) obtained by Aksnes \& Wassmann (1993) for a data set including fjords and estuaries.

\section{Management implications}

The increasing demand for freshwater associated with the increasing population within the ACF (Apalachicola, Chattahoochee and Flint Rivers) River basin motivated the 3 states sharing the $45000 \mathrm{~km}^{2}$ watershed to undertake a comprehensive study of water supply and demand within the system (Lewis 1997). Reduced or altered freshwater flow is responsible for habitat loss and changes in trophic structures in estuaries. Fish populations in San Francisco Bay were reduced as a consequence of habitat loss resulting from reduced freshwater discharge to the estuary (Nichols et al. 1986). In the Skokomish River delta, a $40 \%$ reduction in freshwater flow caused a 15 to $19 \%$ loss of the highly productive intertidal zone and an estimated $17 \%$ loss of eelgrass habitat (Jay \& Simenstad 1996). A 10 -fold decrease in phytoplankton biomass and an increase in benthic macrophytes and detritivory in the estuary were concurrent with a reduction in freshwater inflow following the Kromme River impoundment in South Africa (Baird \& Heymans 1996). 
Fish production depends on transfer of phytoplankton new production through food webs (Iverson 1990). Although Apalachicola Bay phytoplankton carbon productivity is lower during winter high river flow conditions compared to summer low river flow conditions, phytoplankton new production is about 3 times greater during winter (Fig. 10A) compared to summer (Fig. 10B). During summer low flow conditions, Apalachicola Bay primary production is nitrogen-limited (Myers \& Iverson 1981). Phytoplankton new production is relatively low, with regenerated nitrogen supporting most of phytoplankton carbon productivity during summer (Fig. 10B). Therefore, a reduction in Apalachicola River flow into the bay during the summer low flow period, resulting in a reduction in nutrient input to the bay, would negatively affect phytoplankton productivity during that period

Drought conditions over the watershed supplying the Apalachicola River resulted in reduced freshwater input to Apalachicola Bay, which was reflected by significant declines in higher trophic level organism biomass (Livingston et al. 1997). Combining the results of Iverson (1990), Livingston et al. (1997), and the seasonal nitrogen budget results (Fig. 10), a reduction in Apalachicola River flow into the estuary during the summer low flow period would be expected to result in modified food web dynamics and decreased higher trophic level production in Apalachicola Bay.

Acknowledgements. This research was supported by a grant awarded to R.L.I. and W. M. Landing from the Northwest Florida Water Management District and the Florida Department of Environmental Protection. This paper is part of a dissertation submitted to the Department of Oceanography, Florida State University, by B.M. in partial. fulfillment of a $\mathrm{PhD}$ degree. Geoff Schaefer's help in the field and in the laboratory is gratefully acknowledged. Many thanks to C. Bailey, L. Edmiston and the staff of the Apalachicola National Estuarine Research Reserve for their assistance during the sampling. We appreciate the helpful comments of W. M. Landing and 4 anonymous reviewers on an earlier version of this manuscript.

\section{LITERATURE CITED}

Aksnes DL, Wassmann P (1993) Modeling the significance of zooplankton grazing for export production. Limnol Oceanogr 38:978-985

Baird D, Heymans JJ (1996) Assessment of ecosystem changes in response to freshwater inflow of the Kromme River estuary, St. Francis Bay, South Africa: a network analysis approach. Water SA 22:307-318

Benner R, Pakulski JD, McCarthy M, Hedges JI, Hatcher PG (1992) Bulk chemical characteristics of dissolved organic matter in the ocean. Science 255:1561-1564

Bianchi TS, Pennock JR, Twilley RR (1999) Biogeochemistry of Gulf of Mexico estuaries: implications for management. In: Bianchi TS, Pennock JR, Twilley RR (eds) Biogeochem- istry of Gulf of Mexıco estuaries. John Wiley \& Sons, New York, p 407-421

Blumberg AF, Goodrich DM (1990) Modeling of wind-induced destratification in Chesapeake Bay. Estuaries 13:236-249

Blumberg AF, Herring J (1987) Circulation modeling using orthogonal curvilinear coordinates. In: Nihoul JCJ, Jamart BM (eds) Three dimensional models of marine and estuarine dynamics. Elsevier, Amsterdam, p 55-58

Blumberg AF, Mellor GL (1980) A coastal ocean numerical model. In: Sundermann J, Holz KP (eds) Mathematical modeling of estuarine physics. Proceedings of the International Symposium, Hamburg, 24-26 August, 1978. Springer-Verlag, Berlin, p 203-214

Blumberg AF, Mellor GL (1987) A description of a threedimensional coastal circulation model. In: Heaps NS (ed) Three-dimensional coastal ocean models. American Geophysical Union, Washington, DC, p 1-16

Boyd PW, Bury SJ, Owens NJP, Savidge GJ, Preston T (1995) A comparision of isotopic and chemiluminescent methods of estimating microalgal nitrate uptake in the NE Atlantic. Mar Ecol Prog Ser 116:199-205

Boynton WR, Garber JH, Summers R, Kemp WM (1995) Inputs, transformation, and transport of nitrogen and phosphorus in Chesapeake Bay and selected tributaries. Estuaries 18:285-314

Braman RS, Hendrix SA (1989) Nanogram nitrite and nitrate determination in environmental and biological materials by vanadium (III) reduction with chemiluminescence detection. Anal Chem 61:2715-2718

Bronk DA, Ward BB (1999) Gross and net nitrogen uptake and DON release in the euphotic zone of Monterey Bay, California. Limnol Oceanogr 44:573-585

Caffrey JM, Miller LG (1995) A comparison of two nitrification inhibitors used to measure nitrification in estuarine sediments. FEMS Microbiol Ecol 17:213-220

Caffrey JM, Sloth NP, Kaspar HF, Blackburn TH (199.3) Effect of organic loading on nitrification and denitrification in a marine sediment microcosm. FEMS Microbiol Ecol 12: $159-167$

Cameron W. Pritchard D (1963) Estuaries. In: Hill M (ed) The seas: ideas and observations on progress in the study of the seas, Vol 2. John Wiley \& Sons, London, p 306-324

Chanton I (1997) Examination of the coupling between primary production and secondary production in the Apalachicola River and Bay. Florida State University Draft Final Report to the Northwest Florida Water Management District, Havana, FL

Cox RD (1980) Determination of nitrate and nitrite at the parts per billion level by chemiluminescence. Anal Chem 52 : $332-335$

Dugdale RC, Goering JJ (1967) Uptake of new and regenerated forms of nitrogen in primary productivity. Limnol Oceanogr 12:196-206

Eppley RW, Peterson BJ (1979) Particulate organic matter flux and planktonic new production in the deep ocean. Nature 282:677-680

Eppley RW, Renger EH, Harrison WG (1979) Nitrate and phytoplankton production in southern California coastal waters. Limnol Oceanogr 24:483-494

Frick EA, Buell GR, Hopkins EE (1996) Nutrient sources and analysis of nutrient water-quality data, ApalachicolaChattahoochee-Flint River basin, Georgia, Alabama, and Florida, 1972-90. USGS Water-Resource Investigations Report, 96-4101, Atlanta, GA

Fu JM, Winchester JW (1994) Sources of nitrogen in three watersheds of northern Florida, USA: mainly atmospheric deposition. Geochim Cosmochim Acta 58:1581-i590 
Fulmer JM (1997) Nutrient enrichment and nutrient input to Apalachicola Bay, Florida. MSc thesis, Florida State University

Galperin B, Mullor GL (1990) A time-dependent, 3-dimensional model of the Delaware Bay and River system. 2. 3dimensional flow-fields and residual circulation. Estuar Coast Shelf Sci 31:255-281

Galperin B, Kantha LH, Hassid S, Rosati A (1988) A quasiequilibrium turbulent energy model for geophysical flows. J Atmos Sci 45:55-62

Gardner WS, Seitzinger SP, Malczyk JM (1991) The effects of sea salts on the forms of nitrogen released from estuarine and tresh-water sediments-does ion-pairing affect ammonium flux. Estuaries 14:157-166

Garside C (1982) A chemiluminescent technique for the determination of nanomolar concentration of nitrate and nitrite in seawater. Mar Chem 11:159-167

Hallegraeff GM (1993) A review of harmful algal blooms and their apparent global increase. Phycologia 32:79-99

Hess DW (1995) A study of storm and anthropogenic effects on estuarine sedimentation, Apalachicola Bay, Florida. MSc thesis, Florida State University

Howarth $R(1988$ ) Nutrient limitation of net primary production in marine ecosystems. Annu Rev Ecol Syst 19:89-110

Huang W, Jones WK (1997) Three-dimensional modeling of circulation and salinity for the low river flow season in Apalachicola Bay, FL. Northwest Florida Water Management District Water Resources Special Report 97-1, Havana, FL

Humborg C, Ittekkot V, Cociasu A, Bodungen BV (1997) Effects of Danube River dam on Black Sea biogeochemistry and ecosystem structure. Nature 386:385-388

Iverson RL (1990) Control of marine fish production. Limnol Oceanogr 35:1593-1604

Iverson RL, Esaias WE, Turpie K (2000) Ocean annual phytoplankton carbon and new production, and annual export production estimated with empirical equations and CZCS data. Global Change Biol 6(1):57-72

Jay DA, Simenstad CA (1996) Downstream effects of water withdrawal in a small, high-gradient basin: erosion and deposition on the Skokomish River delta. Estuaries 19: $501-517$

Lewis FG (1997) Apalachicola River and. Bay water demand element: summary and integration of Apalachicola Bay studies. Northwest Florida Water Management District Draft Findl Report to the ACF/ACT Comprehensive Study, Havana, FL

Livingston RJ (1984) The ecology of the Apalachicola Bay system: an estuarine profile. US Fish and Wildlife Services, FWS/OSB-82/05, Washington, DC

Livingston RJ, Niu X, Lewis FG III, Woodsum GC (1997) Freshwater input to a gulf estuary: long-term control of trophic organization. Ecol Appl 7:227-299

Mattraw HC, Elder JF (1984) Nutrient and detritus transport in the Apalachicola River, Florida. United States Geological Survey Water Supply Paper 2196-C, Alexandria, VA

Meeter DA, Livingston RJ, Woodsum G (1979) Long-term climatological cycles and population changes in a river-dominated estuarine system. In: Livingston RJ (ed) Ecological processes in coastal and marine systems. Plenum, New York, p 315-338

Mellor GL, Yamada T (1982) Development of a turbulence closure model for geophysical fluid problems. Rev Geophys 20:851-857

Morel A, Andre JM (1991) Pigment distribution and primary production in the western Mediterranean as derived and modeled from coastal zone color scanner observations. J Geophys Res 96:12685-12698

Mortazavi B, Iverson RL, Landing WM, Huang W, Lewis FG (2000) Control of phytoplankton production and biomass in a river-dominated estuary: Apalachicola Bay, FL, USA. Mar Ecol Prog Ser (in press)

Myers VB, Iverson RI (1981) Phosphorus and nitrogen limited phytoplankton productivity in northeastern Gulf of Mexico coastal estuaries. In: Neilson BJ, Cronin LE (eds) Estuaries and nutrients. Humana Press, Clifton, NJ, p 569-582

Nichols FH, Cloern JE, Luoma SN, Peterson DH (1986) The modification of an estuary. Science 231:567-573

Nielsen K, Nielsen LP, Rasmussen P (1995) Estuarine nitrogen retention independently estimated by the denitrification rate and mass balance methods: a study of Norsminde Fjord, Denmark. Mar Ecol Prog Ser 119:275-283

Nixon SW (1995) Coastal marine eutrophication: a definition, social causes, and future concerns. Ophelia 41:199-219

Nixon SW, Ammerman JW, Atkinson LP, Berounsky VM, Billen G, Boicourt WC, Boynton WR, Church TM, Ditoro DM, Elmgren R, Garber JH, Giblin A.E, Jahnke RA, Owens NJP, Pilson MEQ, Seitzinger SP (1996) The fate of nitrogen and phosphorus at the land-sea margin of the North Atlantic Ocean. Biogeochemistry 35:141-180

Nowicki BL, Requintina E, VanKeuren D, Kelly JR (1997) Nitrogen losses through sediment dentrification in Boston Harbor and Massachusetts Bay. Estuaries 20:626-639

Odum EP (1971) Fundamentals of ecology. WB Saunders Philadelphia, PA

Orth RJ, Moore KA (1983) Chesapeake Bay: an unprecedented decline in submerged aquatic vegetation. Science 222:51-53

Paasche E, Kristiansen S (1982) Nitrogen nutrition of the phytoplankton in the Oslofjord. Estuar Coast Shelf Sci 14 $237-249$

Pennock JR, Boyer JN, Herrera-Silveira JA, Iverson RL, Whitledge TE, Mortazavi B, Comin FA (1999) Nutrient behavior and phytoplankton production in Gulf of Mexico estuaries. In: Bianchi TS, Pennock JR, Twilley RR (eds) Biogeochemistry of Gulf of Mexico estuaries. John Wiley \& Sons, New York, p 109-162

Pujo-Pay M, Raimbault P (1994) Improvement of the wet-oxidation procedure for simultaneous determination of particulate organic nitrogen and phosphorus collected on filters. Mar Ecol Prog Ser 105:1-2

Rabalais NN, Wiseman WJ Jr, Turner RE, Justic D, Sen Gupta BK, Dortch Q (1996) Nutrient changes in the Mississippi River and system responses on the adjacent continental shelf. Estuaries 19:386-407

Redfield AC (1958) The biological control of chemical factors in the environment. Am Sci 46:205-221

Rysgaard $\mathrm{S}$, Thastum P, Dalsgaard T, Christensen PB, Sloth NP (1999) Effects of salinity on $\mathrm{NH}_{4}{ }^{+}$adsorption capacity, nitrification, and denitrification in Danish estuarme sediments. Estuaries 22:21-30

Seitzinger SP, Sanders RW (1997) Contribution of dissolved organic nitrogen from rivers to estuarine eutrophication. Mar Ecol Prog Ser 159:1-12

Selmer JS, Ferrier-Pages C, Cellario C, Rassoulzadegan F (1993) New and regenerated production in relation to the microbial loop in the NW Mediterranean Sea. Mar Ecol Prog Ser 100:71-83

Sloth NP, Nielsen LP, Blackburn. TH (1992) Nitrification in sediment cores measured with acetylene inhibition. Limnol Oceanogr 37:1108-1112

Sokal RR, Rohlf FJ (1981) Biometry. WH Freeman and Company, New York 
Strickland JD, Parsons TR (1972) A practical handbook of seawater analysis. Bull Fish Res Board Can 167

Turner RE, Rabalais NN (1994) Coastal eutrophication near the Mississippi River delta. Nature 368:619-621

Twilley RR, Cowan J, Miller-Way T, Montagna P, Mortazavi B (1999) Benthic nutrient fluxes in selected estuaries in the Gulf of Mexico. In: Bianchi TS, Pennock JR, Twilley RR (eds) Biogeochemistry of Gulf of Mexico estuaries. John. Wiley \& Sons, New York, p 163-209

Editorial responsibility: Otto Kinne (Editor), Oldendort/Luhe, Germany van Beusekom JEE, de Jonge VN (1998) Retention of phosphorus and nitrogen in the Ems estuary. Estuaries 21 $527-539$

Wassmann P (1990) Relationship between primary and export production in the boreal coastal zone of the NorthAtlantic. Limnol Oceanogr 35:464-471

Wilber DH (1992) Association between freshwater inflows and oyster productivity in Apalachicola Bay, Florida. Estuar Coast Shelf Sci 35:179-190

Submitted: June 9. 1998; Accepted: October 18, 1999 Proofs received from author(s): March 7, 2000 